\title{
Correction: Dispelling myths about rare disease registry system development
}

\author{
Matthew Bellgard ${ }^{1 *}$, Christophe Beroud ${ }^{2,3}$, Kay Parkinson $^{4}$, Tess Harris ${ }^{5}$, Segolene Ayme ${ }^{6}$, Gareth Baynam,8,9, \\ Tarun Weeramanthri ${ }^{10}$, Hugh Dawkins $s^{1,10,11,12}$ and Adam Hunter ${ }^{1}$
}

\section{Correction}

After publication of this work [1], we noted that we inadvertently failed to include important Acknowledgments in our final version of the manuscript. Please see below the modification:

\section{Acknowledgements}

The authors received funding from the Australian National Health and Medical Research Council (APP1055319) and EU FP7 Project (HEALTH.2012.2.1.1-1-C): RD Connect: An integrated platform connecting databases, registries, biobanks and clinical bioinformatics for rare disease research. The authors wish to acknowledge their involvement in the International Rare Disease Research Consortium.

\section{Author details}

${ }^{1}$ Centre for Comparative Genomics, Murdoch University, Perth 6150, Western Australia. ${ }^{2}$ Faculté de Médecine de la Timone, INSERM UMR 910, Aix-Marseille Université, Marseille, France. ${ }^{3}$ AP-HM, Département de Génétique Médicale, Hôpital d'enfants Timone, Marseille, France. ${ }^{4}$ Alstrom Syndrome, 49 Southfield Ave, Paignton S, Devon TQ3 1LH, UK. ${ }^{5}$ Polycystic Kidney Disease Charity (UK), PKD International, Ciliopathy Alliance, London, UK. ${ }^{6}$ INSERM US14, ORPHANET 96 rue Didot, Paris 75014, France. ${ }^{7}$ Genetic Services of Western Australia, King Edward Memorial Hospital, Perth, Western Australia. ${ }^{8}$ School of Paediatrics and Child Health, University of Western Australia, Perth, Western Australia. ${ }^{9}$ Institute for Immunology and Infectious Diseases, Murdoch University, Perth, Western Australia. ${ }^{10}$ Office of Population Health Genomics, Public Health and Clinical Services Division, Department of Health, Government of Western Australia, Perth, Western Australia. ${ }^{11}$ School of Pathology \& Laboratory Medicine, University of Western Australia, Perth, Western Australia. ${ }^{12}$ Curtin Health Innovation Research Institute, Curtin University of Technology, Perth, Western Australia.
Received: 17 January 2014 Accepted: 28 January 2014 Published: 31 January 2014

\section{Reference}

1. Bellgard M, Beroud C, Parkinson K, Harris T, Ayme S, Baynam G, Weeramanthri T, Dawkins H, Hunter A: Dispelling myths about rare disease registry system development. Source Code Biol Med 2013, 8:21.

doi:10.1186/1751-0473-9-4

Cite this article as: Bellgard et al:: Correction: Dispelling myths about rare disease registry system development. Source Code for Biology and Medicine 2014 9:4.

\footnotetext{
*Correspondence: mbellgard@ccg.murdoch.edu.au

${ }^{1}$ Centre for Comparative Genomics, Murdoch University, Perth 6150, Western Australia

Full list of author information is available at the end of the article
}

\section{Submit your next manuscript to BioMed Central and take full advantage of:}

- Convenient online submission

- Thorough peer review

- No space constraints or color figure charges

- Immediate publication on acceptance

- Inclusion in PubMed, CAS, Scopus and Google Scholar

- Research which is freely available for redistribution

Submit your manuscript at www.biomedcentral.com/submit 